\title{
KEPEMIMPINAN POLITIK PEREMPUAN DALAM PEMIKIRAN MUFASSIR
}

\author{
Halimah B.
}

Fakultas Syariah dan Hukum Universitas Islam Negeri (UIN) Alauddin Makassar

\begin{abstract}
The majority of contemporary mufassirs do not prevent women from becoming leaders in the public sphere by QS. al-Taubah / 9: 71. Besides being supported by historical facts, Queen Balqis is the ruler of the country of Saba' as is told al-Qur'an in surah al-Naml. Leadership is a success, the country prospers with democratic attitudes and views. In addition, historical facts in the time of the Prophet of many women engaged in political roles and even involved in practical politics including the wife of the Prophet. Aishah himself led the battle against 'Ali ibn Talib
\end{abstract}

\section{Keywords:}

Leadership, politics, women and mufassir.

\begin{abstract}
Abstrak
Mayoritas mufassir kontemporer tidak menghalangi perempuan menjadi pemimpin dalam ranah publik berdasarkan QS. al-Taubalaah /9:71. Di samping ditunjang fakta-fakta sejarah, Ratu Balqis penguasa negeri Saba,'seperti yang diceritakan al-Qur'an dalam surah al-Naml. Kepemimpinannya terbilang sukses, negaranya makmur dengan sikap dan pandangannya yang demokratis. Selain itu, fakta historis pada masa Rasulullah banyak kaum perempuan terlibat dalam peran-peran politik dan bahkan terlibat dalam politik praktis termasuk istri Rasulullah saw. sendiri Aisyah r.a memimpin langsung peperangan melawan 'Ali ibn Talib.
\end{abstract}

Kata Kunci:

Kepemimpinan, politik, perempuan dan mufassir.

\section{A. PENDAHULUAN}

W

acana kepemimpinan perempuan menjadi polemik dan pro-kontra dikalangan mufassir. Hal ini terjadi karena satu sisi ditemukan penafsiran ayat dan hadith secara tekstual mengutamakan laki-laki menjadi pemimpin. ${ }^{1}$ Meskipun sebahagian mereka membolehkan perempuan menjadi pemimpin dalam masyarakat (publik), dengan menjadikan QS. al-Taubah /9:71

${ }^{1}$ Istibsyaroh, Hak-Hak Perempuan Relasi Jender Menurut Tafsir al-Sya'rawi (Jakarta: Teraju, 2004), 177. 
sebagai landasan kebolehannya dengan kontektualisasi penafsiran. Di samping itu fakta menunjukkan ada sejumlah perempuan berpengaruh dalam masyarakat dan mempunyai kemampuan menjadi pemimpin.

Perdebatan yang terjadi tentang kepemimpinan perempuan di kalangan mufassir. Pertama; sebahagian mereka mendasarkan pandangannya QS. al-Nisa'/4:34 bahwa laki-laki mutlak menjadi pemimpin. Penafsiran tersebut memberikan reaksi kepada sebahagian kalangan Islam bahwa Islam diskriminatif terhadap perempuan yang dapat menjadi pemimpin. Oleh karenanya ada bias pemahaman yang menyebabkan ketidakadilan dalam kepemimpinan bagi perempuan. Kedua; mereka berpegang terhadap penegasan hadith Rasulullah saw. " tidak akan beruntung suatu kaum yang menyerahkan urusan mereka kepada seorang perempuan".

Islam begitu memuliakan kaum perempuan, memberinya kebebasan pribadi dan menghormatinya, memberinya hak-hak kepadanya, bukan karena pilih kasih terhadap dirinya, melainkan untuk mewujudkan tujuan terbesar Islam untuk menghormati manusia secara keseluruhan dan mengangkat kehidupan manusia. Semua ayat dan hadith yang menyatakan keutamaan derajat manusia selalu tidak membedakan antara laki-laki dan perempuan. Al-Qur'an menggunakan istilah yang netral dalam pengungkapan tersebut, misalnya disebutkan dalam QS.al-Isra' [17]:70.2

Dalam al-Qur'an dan hadith tidak ditemukan larangan perempuan menjadi pemimpin baik dalam ranah domestik maupun publik. Karena itu perlu dianalisa pemikiran mufassir terhadap ayat QS.al-Nisa' dan QS.al-Taubah tersebut serta hadith Rasulullah saw. riwayat Imam Bukhari yang bersumber dari Abu Bakrah. Hal ini dilakukan untuk memperoleh penafsiran yang relevan dengan masa kini.

\section{B. ANALISIS AYAT KEPEMIMPINAN PEREMPUAN}

Kepemimpinan perempuan menjadi perdebatan di kalangan para pakar dan sebahagian mufassir. Sebahagian berpendapat bahwa kepemimpinan mutlak dipegang oleh laki-laki. Pendapat lain mengatakan bahwa perempuan boleh juga menjadi pemimpin baik dalam ranah publik maupun dalam ranah domestik (rumah tangga). Hal ini dikarenakan perbedaan penafsiran QS. al-Nisa' [4:34]. :

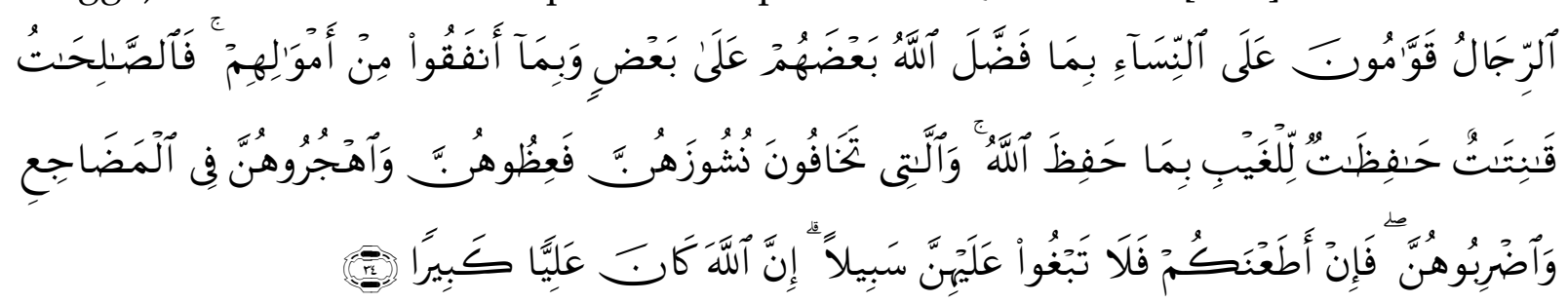

${ }^{2}$ QS. al-Isra' [17]: 70:

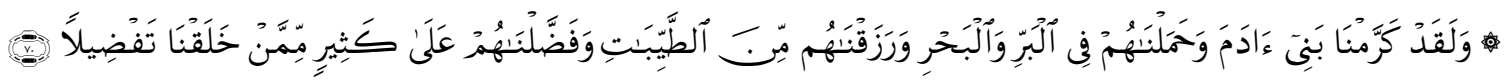

"Dan sesungguhnya telah Kami muliakan anak-anak Adam, Kami angkat mereka di daratan dan di lautan, Kami beri mereka rezeki dari yang baik-baik dan Kami lebihkan mereka dengan kelebihan yang sempurna atas kebanyakan mahluk yang telah Kami ciptakan." 
Terjemahnya:

Kaum laki-laki adalah pemimpin bagi kaum wanita, oleh karena Allah telah melebihkan sebahagian mereka (laki-laki) atas sebahagian yang lain (wanita), dan mereka (laki-laki) telah menafkahkan sebagian dari harta mereka. Sebab itu maka wanita yang saleh, ialah yang taat kepada Allah lagi memelihara diri ketika suaminya tidak ada, oleh karena Allah memelihara (mereka). Wanita-wanita yang kamu khawatirkan nusyuznya, maka nasehatilah mereka, dan pisahkan mereka di tempat tidur mereka, dan pukullah mereka. Kemudian jika mereka mentaatimu, maka janganlah kamu mencari-cari jalan untuk menyusahkannya, sesungguhnya Allah Maha Tinggi lagi Maha Besar. ${ }^{3}$

Ada dua lafaz yang menarik dikaji dalam ayat ini yaitu lafaz al-rijal dan qawwamun.

Pertama, Lafaz al-rijal dalam ayat ini sering dijadikan perdebatan oleh para pakar. Al-Sabuni menyatakan bahwa seseorang yang dapat dijuluki dengan rujulah (jantan) adalah bagi mereka yang telah dikaruniakan oleh Allah kelebihan akal, kepemimpinan, kelebihan kasab, dan nafqah. ${ }^{4}$ Ibnu Kathir berpandangan bahwa laki-laki adalah pemimpin bagi kaum perempuan. Karena laki-laki lebih afdal dari pada perempuan, laki-laki lebih baik dari pada perempaun, karena itulah maka nubuwwah (kenabian) hanya khusus bagi kaum laki-laki. ${ }^{5}$ Dengan karakteristik lakilaki dan perempuan yang berlainan itulah, pandangan kedua mufassir ini disimpulkan bahwa laki-laki memang lebih unggul dari pada perempuan. Posisi laki-laki dan perempuan sudah tidak setara secara alamiah dengan adanya keunggulan-keunggulan tersebut.

Istilah-istilah gender dalam al-Qur'an mempunyai makna yang signifikan untuk diluruskan. Misalnya ayat yang berkaitan dengan kepemimpinan, QS.alNisa'[4:34], di mana kata al-rijal dikaitkan dengan al-Nisa'. Kata al-Nisa' dikonotasikan sebagai feminim, domestikal, lemah lembut, bahkan banyak lupa. ${ }^{6}$ Sementara rijl bisa bermakna orang yang berjalan kaki, ${ }^{7}$ jadi makna sosiologis dalam pengertian di atas, laki-laki berjalan mencari nafkah dan perempuan tinggal di rumah. ${ }^{8}$ Zaitunah Subhan menjelaskan bahwa yang dimaksud kata qawwamun di dalam ayat ini bisa saja diartikan laki-laki dan bisa juga diartikan untuk perempuan. Karena secara sosiologis siapa pun yang mampu (baik laki-laki maupun perempuan)

\footnotetext{
${ }^{3}$ Departemen Agama RI, al-Qur'an dan Terjemahnya (Jakarta: Yayasan Penyelenggara Penerjemah/Penafsir al-Qur'an, 1971. 123.

${ }^{4}$ Muhammad 'Ali al-Sabuni, Safwat al-Tafasir (Beyrut: Dar al-Qur'an al-Karim, 1981), Jilid I, 274.

${ }^{5}$ Abi al-Fida Isma 'il Ibn Kathir, Tafsir Ibnu Kathir (Beyrut: Dar al-Fikr, 1986), 482.

${ }^{6}$ Louis Makhluf al-Yasu'i, al-Munjid fi al-Lughah wa al-Adab wa al-'Ulum (Beyrut: al-Kathulikiyyah, 1986), 807.

${ }^{7}$ Louis Makhluf al-Yasu'i, al-Munjid al-Lughah, 251. Husayn bin Muhammad al-Asfahani, al-Mufradat fi Gharib al-Qur'an (Kairo: Mustafa al-Babi al-Halabi, 1961), 190.

${ }^{8}$ Zaitunah Subhan memahami ayat tersebut secara sosiologis, ia memulai dengan menafsirkan kata al-Rijl sebagai orang yang suka melakukan perjalanan karena laki-laki pada waktu turunnya ayat ini, sebagai yang mencari nafkah. Sementara penamaan perempuan dengan kata al-Nisa' dianggap kaum yang lemah karena menunggu suaminya di rumah. Zaitunah Subhan, Rekonstruksi Pemahaman Gender dalam Islam : Agenda Sosio Kultural dan Politik Peran Perempuan (Jakarta: El-Kahfi, 2002),176-177.
} 
untuk berupaya mengayomi nafkah keluarga maka dialah qawwamun, dialah al-rijal. ${ }^{9}$

Kekurangakuratan dalam memahami lafaz rujulah melahirkan sikap negatif terhadap perempuan, sehingga dalam realita kehidupan ada implikasi dari penafsiran lafaz tersebut untuk melakukan tindakan sewenang-wenang terhadap perempuan. Oleh karenanya perlu merekonstruksi kembali penafsiran kata rujulah untuk tidak terjadinya ketidakadilan dan bias gender dalam rumah tangga.

Muhammad Tahir Ibnu'Ashur (1879-1973) mengatakan yang dimaksud dengan al-rijal dalam ayat ini ialah pribadi yang mempunyai naluri kelelakian, dan ini juga yang dimaksud laki-laki dari jenis kelamin. Demikian juga yang dimaksud dengan perempuan dari jenis kelamin. Kata al-rijal dalam ayat ini, bukanlah seluruh laki-laki akan tetapi yang dimaksud di sini laki-laki dalam pengertian suami, demikian juga yang dimaksud al-nisa' dalam ayat ini bukanlah semua perempuan, tetapi yang dimaksud dalam ayat ini perempuan dalam pengertian istri. ${ }^{10}$

Analisis ini cukup beralasan, menurut kaedah bahasa Arab lafaz yang menggunakan "al"(alif lam) adalah dikategarikan isim ma'rifah (menunjuk arti khusus). Maka lafaz al-rijal dan al-nisa' adalah isim ma'rifah yang menunjukkan orang tertentu, oleh karenanya maka yang dimaksud dengan al-rijal dalam ayat ini adalah laki-laki tertentu yaitu suami tidak mencakup semua laki-laki. Demikian juga yang dimaksud dengan al-nisa' dalam ayat ini adalah perempuan tertentu yaitu istri tidak mencakup semua perempuan. Di samping itu juga jika lafaz ini dikaitkan dengan kalimat sesudahnya (munasabah) ${ }^{11}$ dengan frase(wa bima anfaqu min amwalihim) semakin kuat ayat ini dalam rangka membicarakan konteks keluarga sehingga lebih mengindikasikan bahwa yang dimaksud dengan al-rijal adalah suami sebagai pemimpin dalam rumahtangga (kepala rumahtangga) bukan sebagai pemimpin secara umum, termasuk pemimpin dalam mengelola negara (kepala negara), dan al-nisa' adalah istri sebagai anggota keluarga yang dipimpin. Dengan demikian maka yang dimaksud dengan al-rijalu qawwamuna 'ala al-nisa adalah laki-

\footnotetext{
${ }^{9}$ Kata qawwamun harus dipahami dengan kontekstual-substantif yaitu kepemimpinan rumah tangga disesuaikan dengan konteks sosial tertentu dan bersifat relatif. Zaitunah Subhan, Rekonstruksi Pemahaman Gender Dalam Islam: Agenda Sosio Kultural dan Politik Peran Perempuan , 74.

من النسأكم اللآتى دخلتم بهن "10 “(dan istri-istri kamu yang telah kamu gauli). Akan tetapi yang dimaksud ialah apa yang ditunjuk oleh lafaz berdasarkan dasar peletakannya. Contoh firman Allah” (bagi perempuan mendapat bagian sesuai dengan apa yang diusahakannya). Muhammad Tahir Ibnu 'Ashur, al-Tahrir wa al-Tanwir, Jilid 5, 38. Kata al-rijal tidak mencakup semua laki-laki, melainkan hanya laki-laki tertentu, selain itu kata tersebut menggunakan "al" (alif lam) yang menunjuk pada arti definitif. Dengan demikian ayat ini lebih tepat diartikan hanya laki-laki yang memiliki kualifikasi tertentu yang bisa menjadi pemimpin atas perempuan tertentu. Apalagi jika ditelusuri sebab turunnya ayat ini diturunkan dalam konteks kehidupan suami istri. Dari perspektif ini bermakna bahwa suami tertentu saja yang dapat menjadi pemimpin bagi istrinya dan kepemimpinannya terbatas di ruang domestik dengan catatan suami harus menjalankan kepemimpinanya tidak otoriter dan sewenangwenang. Siti Musdah Mulia, Menuju Kemandirian Politik Perempuan (Upaya Mengakhiri Depolitisasi Perempuan di Indonesia) (Yogyakarta: Kibar Press, 2007), 142-143.

${ }^{11}$ Munasabah antara kalimat al-rijal dengan kalimat ba'duhum dan wa bima anfaqu min amwalihim bahwa yang dibebani mengeluarkan nafkah dan membayar mahar adalah laki-laki. Berbicara tentang nafqah dan mahar berarti masuk dalam lingkup keluarga,oleh karenanya ayat ini menjelaskan tentang kepemimpinan dalam rumah tangga bukan kepemimpinan secara umum.
} 
laki sebagai suami menjadi pemimpin yang memiliki kewajiban memberi nafkah kepada istri dan anak-anaknya dalam keluarga. Dalam pengertian bahwa kepemimpinan dalam ayat QS. al-Nisa' [4:34] tersebut menunjukkan kepemimpian dalam rumah tangga (domestic) bukan kepemimpinan secara umum (publik).

Sayyid Qutb (1906-1966) menganggap masalah qiwamah sebagai masalah yang berkaitan dengan keluarga. Dia membatasi pada ayat ini dalam konteks hubungan suami istri (rumahtangga). Menurutnya apa yang diberikan laki-laki kepada perempuan yakni memberikannya keistimewaan untuk menjadi qawwamuna 'ala alnisa (pemimpin bagi perempuan). Dengan demikian, maka qiwamah (kepemimpinan) dalam rumah tangga ini berada di tangan laki-laki. Disebutkan bahwa ada dua alasan kepemimpinan dalam keluarga jatuh ke tangan laki-laki, pertama; karena Allah melebihkan laki-laki dengan tanggung jawab kepemimpinan beserta kekhususan-kekhususan dan keterampilan yang dibutuhkannya Kedua; tugas laki-laki memberi nafkah kepada seluruh anggota keluarga ini. ${ }^{12}$ Didasarkan atas pemberian kekuasaan kepada kaum laki-laki ini, maka dibatasi pulalah hak istimewa kepemimpinan ini dalam menjaga intitusi rumah tangga dari keretakan, menjaganya dari berbagai keinginan yang bermunculan, mencari jalan pemecahan ketika terjadi perselisihan dalam batas-batas tertentu.

Lafaz kedua, qawwamun. Ayat QS.al-Nisa [4]:34 ini menjadi salah satu ayat yang mengundang perhatian bagi para mufassir kontemporer, dan para peneliti gender yaitu hambatan bagi kaum perempuan untuk menjadi pemimpin.

Dalam Khazanah Tafsir al-Qur'an ada beberapa pendapat tentang makna kata qawwamun. Ibnu 'Ashur berpendapat bahwa qawwamun di sini adalah kepemimpinan laki-laki terhadap perempuan yaitu kepemimpinan dalam arti menjaga, membela, dan kepemimpian dalam berusaha dan menghasilkan harta, dengan demikian Allah menjelaskan (bima faddalalallahu ba'duhum 'ala ba'd wa bima anfaqu min amwalihim) "Allah memberikan kelebihan kepada laki-laki karena dia yang mengeluarkan nafqah. ${ }^{13}$

Menurut Nasaruddin Umar kata qawwamun bisa diartikan pendamping, pemelihara, atau penanggung jawab, yang lebih berkonotasi fungsional. Kata pemimpin dalam bahasa Indonesia tidak identik dengan qawwamah dalam bahasa Arab. Nasaruddin Umar membandingkan dengan terjemahan Yusuf Ali menerjemahkan ke dalam bahasa Inggris dengan man are the protectors and maintainers of women (laki-laki adalah pelindung dan pemelihara bagi perempuan). ${ }^{14}$ Sementara M.Quraish Shihab menjelaskan qawwamun, dapat dipahami dalam ayat ini kenapa Allah swt. menunjuk laki-laki sebagai pemimpin dalam rumah tangga, karena lakilaki memang memiliki kelebihan baik secara fisik maupun psikis, dan adanya

\footnotetext{
${ }^{12}$ Sayyid Qutb, Fi Zilal al-Qur'an (Tunis: Dar Sahnun, 2011), Jilid 2, 649.

${ }^{13}$ Muhammad Tahir Ibnu 'Ashur, al-Tahrir wa al-Tanwir (Tunis: Dar Sahnun li al-Nashr wa al-Tawzi,' t.th. ), Jilid 5, 38.

${ }^{14}$ Nasaruddin Umar, Ketika Fikih Membela Perempuan (Jakarta: PT.Gramedia, 2014), 188. Nasaruddin Umar, Argumen Kesetaran Gender Perspektif al-Qur'an, (Jakarta: Paramadina, 2001), 150.
} 
perintah kewajiban bagi suami untuk menafkahi istri dan keluarga. ${ }^{15}$

Pandangan Nasaruddin Umar di atas dalam hal ini adanya keutamaan laki-laki dalam ayat ini hanya disebabkan oleh tugasnya sebagai pencari nafkah. Sementara M. Quraish Shihab kelihatannya lebih cenderung pada pembagian peran laki-laki yang lebih produktif dan peran perempuan yang cenderung reproduktif.

Al-Taba'taba'i menyatakan bahwa laki-laki disebut sebagai pemimpin dan pengayom bagi perempuan karena laki-laki berfikir lebih rasional dari pada perempuan. ${ }^{16}$ Pernyataan bahwa laki-laki lebih rasional dari pada perempuan dimaksudkan adalah laki-laki biasanya lebih cenderung mengedepankan rasio dari pada perasaan, sementara perempuan selain mengedepankan rasio juga mengedepankan perasaan.

Senada Zaitunah Subhan bahwa ayat di atas kata qawwamun hanya berfungsi sebagai khabar (menurut gramatika bahasa Arab), bukan perintah (amar) bahwa laki-laki harus menjadi pemimpin (qawwamun) bagi perempuan sebagai pernyataan normatif. Di samping itu ayat di atas menjelaskan keunggulan laki-laki sebagai pencari nafkah dan membelajakannya untuk istri adalah keunggulan fungsional. Dalam realitas sosial, banyak kaum perempuan yang mandiri secara ekonomi, bahkan menjadi tulang punggung keluarga, meskipun masih ada pandangan dan bahkan pengakuan Yuridis yang menganggap penghasilan mereka sebagai tambahan belaka. ${ }^{17}$

Argumen ini cukup beralasan, sebab realitas dan faktanya saat ini di mana banyak perempuan menjadi anggota DPR, menteri, direktur perusahaan, menjadi guru, dosen, pimpinan perguruan tinggi, dan seterusnya tentu saja tampak lebih mapan dan bahkan bisa menjadi tulang punggung yang menafkahi seluruh keluarganya, sehingga kepemimpinan dalam keluarga bisa juga dipegang oleh perempuan.

Berdasarkan pemaparan di atas dapat disimpulkan bahwa berdasarkan konteks ayat tersebut maka kepemimpinan dalam rumah tangga berada di tangan laki-laki sebagai suami dengan kelebihan yang dimiliki. Namun, bagaimana jika melihat realitas dan fakta saat ini banyak perempuan (istri) menanggung biaya hidup menjadi (tulang punggung) keluarga karena laki-laki (suami) tidak mampu bekerja karena beberapa alasan, misalnya karena mengidap penyakit menahun yang tidak bisa disembuhkan, otomatis suami tidak dapat menunaikan tanggung jawabnya sebagai pemimpin dan kepala rumah tangga serta kelebihan yang dimiliki juga tidak bisa difungsikan. Atau karena suami lemah atau memang tidak mempunyai kemampuan berusaha, atau karena suami sudah meninggal dunia, dalam kondisi

${ }^{15}$ M. Quraish Shihab, Tafsir al-Misbah, Pesan, Kesan dan Keserasian al-Qur'an (jakarta: Lentera Hati, 2008), Vol II, 404. 343.

${ }^{16}$ Muhammad Husayn al-Taba’taba'i, Tafsir al-Mizan, (Teheran: Dar al-Kutub al-'Ilmiyah,t.th.), Juz IV,

${ }^{17}$ Zaitunah Subhan, Perempuan dan Politik dalam Islam (Yogyakarta: Pustaka Pesantren, 2004), Cet. ke$1,30-31$. 
seperti ini tanggung jawab sebagai kepala rumah tangga boleh diambil alih perempuan (istri). Karena itu sejatinya ayat ini dipahami secara kontekstual sehingga tidak terjadi ketimpangan dalam relasi gender.

Harus diakui ada sementara ulama yang menjadikan surah al-Nisa'[4:34) tersebut sebagai argumen menolak perempuan menjadi pemimpin dalam ranah publik, apalagi menjadi kepala negara. Menurut mereka kepemimpinan berada di tangan laki-laki, sehingga hak-hak berpolitik pun berada di tangan mereka. Pandangan ini tidak sejalan dengan makna sebenarnya yang diamanatkan oleh ayat yang disebutkan itu. Nasaruddin Umar menyatakan bahwa ayat di atas tidak dapat dijadikan alasan untuk menolak perempuan menjadi pemimpin di dalam masyarakat. ${ }^{18}$ Dia juga mendukung pendapat Muhammad 'Abduh dalam al-Manar yang menjelaskan bahwa laki-laki tidaklah mutlak sebagai pemimpin bagi perempuan, karena ayat ini tidak menggunakan kata " ma faddalahum bihinna atau bi fadhilim 'alaihinna" (oleh karena Allah memberikan kelebihan pada laki-laki atas perempuan), tetapi menggunakan ungkapan: “ bi ma faddalallahu ba'duhum 'ala ba'd (Allah memberikan kelebihan sebagian mereka terhadap sebagian yang lain). ${ }^{19}$

Argumen ini cukup beralasan karena ayat ini berbicara dalam konteks urusan keluarga, tidak ada hubungannya dengan soal hak politik perempuan. Demikian juga kepemimpinan dalam masyarakat tidak ada kaitannya dengan kewajiban memberi nafkah terhadap masyarakat yang dipimpinnya, tetapi hanya berkaitan dengan kewajiban melaksanakan tanggungjawabnya dan menegakkan keadilan terhadap masyarakat yang dipimpinnya.

Tidak ditemukan dalil, baik ayat al-Qur'an atau pun hadith yang melarang perempuan menjadi pemimpin baik dalam ranah domestik maupun publik. Salah satu ayat yang sering dikemukakan oleh para pemikir Islam yang mengisyaratkan kemungkinan perempuan menjadi pemimpin di dalam masyarakat seperti QS. alTawbah [9:71] :

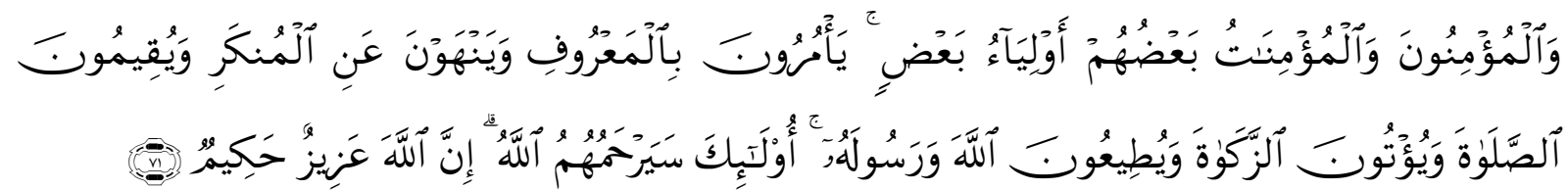

Terjemahnya:

Dan orang-orang yang beriman, lelaki dan perempuan, sebahagian mereka (adalah) menjadi penolong bagi sebahagian yang lain. Mereka menyuruh (mengerjakan) yang ma'ruf,

\footnotetext{
${ }^{18}$ Nasaruddin Umar, Argumen Kesetaraan Gender Perspektif al-Qur'an, 150. Menurut Jamaluddin Muhammad Mahmud bahwa kepemimpinan laki-laki terhadap perempuan yang terkandung dalam QS.alNisa'[4]:34 adalah kepemimpinan dalam keluarga, itu hak yang tidak diragukan lagi, karena itu hukum syar'i dan realitas kehidupan dalam segala zaman. Namun perempuan itu harus di rumah jangan kita menjadikan dia selalu ada di rumah, tetapi harus diarahkan ke tempat di mana dia melakukan pekerjaannya dan tempat menyampaikan misinya yang mulia dalam kehidupan. Apabila dia ikut serta dalam urusan masyarakat, maka harus keluar dari rumahnya untuk menyempurnakan risalahnya. Jamaluddin Muhammad Mahmud, Huquq alMar'ah (Mesir: al-Haiah al-Misriyah al-'Ammah li al-Kitab, 1986), 65.

${ }^{19}$ Rashid Rida, Tafsir al-Manar, Jilid 5, (Kairo: Dar al-Manar, t.th.), 68.
} 
mencegah dari yang munkar, mendirikan sembahyang, menunaikan zakat, dan mereka taat kepada Allah dan Rasul-Nya. Mereka itu akan diberi rahmat oleh Allah; sesungguhnya Allah Maha Perkasa lagi Maha Bijaksana.

Secara umum, ayat di atas dipahami sebagai gambaran tentang kewajiban melakukan kerjasama antara laki-laki dan perempuan dalam berbagai bidang kehidupan yang dilukiskan dengan kalimat menyuruh mengerjakan yang ma'ruf dan mencegah yang munkar

Kata awliya' dalam ayat ini menurut Quraish shihab mencakup kerjasama, bantuan, dan penguasaan, sedangkan pengertian menyuruh mengerjakan yang ma'ruf mencakup segala segi kebaikan, termasuk memberi nasehat atau kritik kepada penguasa. ${ }^{20}$ Senada dengan al-Sya' rawi menafsirkan kata awliya' mengatakan bahwa dalam masyarakat mukmin harus tolong menolong dan saling memberi nasehat agar sempurna imannya. ${ }^{21}$ Sedangkan kandungan dari frase menyuruh mengerjakan yang ma'ruf dan mencegah yang munkar, yakni ketika mukmin mengerjakan perkara munkar, maka mukmin yang lain mencegahnya dan ketika mukmin tidak mengerjakan kebaikan, maka mukmin yang lain mengingatkanannya. Akhirnya setiap mukmin memerintah dan diperintah untuk mengerjakan kebaikan dan melarang mengerjakan kemunkaran. ${ }^{22}$

Menurut Muhammad Tahir Ibnu 'Ashur (1879-1973) kata awliya' mengandung makna bahwa yang menghimpun orang-orang mukmin adalah keimanan yang mantap serta dapat mengaplikasikan sikap tolong-menolong yang diajarkan Islam. Tidak seorangpun yang bertaklid kepada yang lain atau mengikutinya tanpa kejelasan dalil. ${ }^{23}$

Pendapat Sayyid Qutb sedikit berbeda, menurutnya, walaupun tabiat sifat munafik sama dan sumber ucapan dan perbuatan itu sama, yakni ketiadaan iman, kebejatan moral, dan lain-lain, persamaan itu tidak mencapai tingkat yang menjadikan mereka awliya' (penolong) bagi sebagian yang lain. Karena untuk mencapai tingkat awliya' dibutuhkan keberanian, tolong menolong, bantu membantu, biaya dan tanggungjawab serta rasa senasib sepenanggungan. ${ }^{24}$ Sementara Nasaruddin Umar, berpendapat kata awlya' dapat berarti pemegang otoritas, tentu bukan saja di dalam dunia domestik tetapi juga di dunia publik. ${ }^{25}$

Dari beberapa pengertian tersebut dapat disimpulkan bahwa makna awliya dalam ayat ini adalah pemegang otoritas atau penguasa baik dari kaum laki-laki maupun perempuan. Keduanya harus bekerjasama, tolong menolong dan keduanya berhak menyuruh mengerjakan yang ma'ruf dan mencegah yang munkar.

\footnotetext{
${ }^{20}$ M.Quraish Shihab, Wawasan al-Qur'an: Tafsir Maudhu'i atas Pelbagai Persoalan Umat (Bandung:Mizan, 1998), 315.

${ }^{21}$ Al-Sya'rawi, Tafsir al-Sya'rawi, Jilid 9 (Kairo: Shirkah al-Sawtiyah wa al-Mar'iyyah, t.th.), 5287.

${ }^{22}$ Al-Sya 'rawi, Tafsir al-Sya 'rawi,Jilid 9, 5293.

${ }^{23}$ Muhammad Tahir Ibnu 'Ashur, al-Tahrir wa al-Tanwir, Jilid 10 (Tunis: Dar Sahnun, t.th.), 262.

${ }^{24}$ Sayyid Qutb, Fi Zilal al-Qur'an, Jilid 3, (Kairo: Dar al-Shuruq, 2011), 1675.

${ }^{25}$ Nasaruddin Umar, Ketika Fikih Membela Perempuan (Jakarta: PT.Gramedia, 2014), 199.
} 
Islam memberi kebebasan berpendapat dan berfikir kepada perempuan, boleh mengemukakan pendapat dalam bermusyawarah. Salah satu ayat menyatakan hal ini dalam QS. 'Ali 'Imran [3]: 159. ${ }^{26}$ Islam tidak membatasi hak perempuan dalam mengurus seluruh kepentingan publik. Hanya saja perlu disesuaikan dengan kemampuan dan kehormatan perempuan itu sendiri. ${ }^{27}$

Ayat tersebut menjelaskan setiap warga negara, hendaknya berpartisipati mengelola kehidupan bersama masyarakat. Perempuan dan laki-laki mempunyai hak dalam mengatur kepentingan umum, termasuk di dalammya ya'muruna bi alma 'ruf wa yanhawna 'an al-munkar (menyuruh pada kebaikan dan mencegah kemunkaran). Dalam ayat ini dijelaskan juga bahwa perempuan mampu mengemukakan pendapat yang benar, berpartisipasi dalam kegiatan politik dan bertanggung jawab atas segala tindakannya. Perempuan memiliki hak politik sama dengan laki-laki. Perempuan berhak menduduki seluruh jabatan politik, termasuk menjadi kepala negara. ${ }^{28}$ Menurut Ibrahim Hashim Ibrahim bahwa ayat ini adalah kewajiban kepada laki-laki dan perempuan menyuruh yang ma'ruf dan melarang yang munkar baik melalui perkataan (ucapan) atau melalui tulisan, .dan lainnya, termasuk juga perempuan memberi pelajaran tentang hal-hal yang ma'ruf dan yang mungkar. ${ }^{29}$

Perempuan diidealkan memiliki kemandirian politik (al-istiqlal al-siyasah) disebutkan dalam QS. al-Mumtahanah [60]: 12, Ratu Balqis sosok perempuan penguasa yang mempunyai kerajaan superpower, perempuan juga memiliki kemandirian ekonomi (al-istiqlal al-Iqtisadi) sebagaimana dalam QS. al-Nahl [16]: 97, seperti pemandangan yang disaksikan Nabi Musa di Madyan, perempuan pengelola peternakan dalam QS. al-Qasas [28]: 23, memiliki kemandirian dalam menentukan pilihan-pilihan pribadi (al-istiqlal al-Shakhsi) yang diyakini kebenarannya, sungguhpun harus menghadapi suami bagi perempuan yang sudah berkeluarga disebutkan dalam QS. al-Tahrim [66]: 11, atau menantang opini publik bagi perempuan yang belum berkeluarga dalam QS. al-Tahrim [66]: 12. Bahkan al-Qur'an menyerukan perjuangan terhadap suatu bangsa yang menindas kaum perempuan

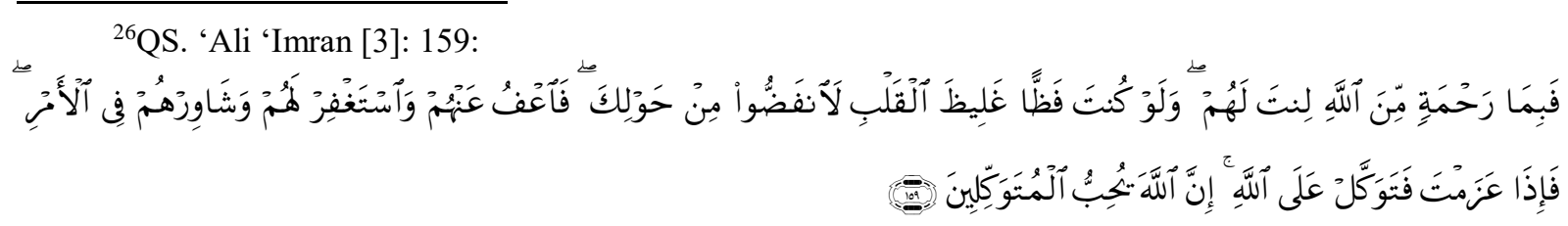

Maka disebabkan rahmat dari Allah-lah kamu berlaku lemah lembut terhadap mereka. Sekiranya kamu bersikap keras lagi berhati kasar, tentulah mereka menjauhkan diri dari sekelilingmu. Karena itu maafkanlah mereka, mohonkanlah ampun bagi mereka, dan bermusyawaralah dengan mereka dalam urusan itu. Kemudian apabila kamu telah membulatkan tekad, maka bertawakkallah kepada Allah. Sesungguhnya Allah menyukai orang-orang yang bertawakkal kepada-Nya.

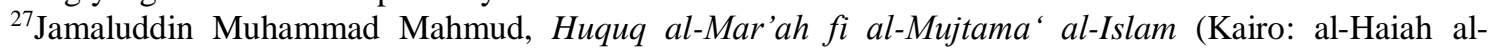
Misriyah al-'Ammah li al-Kitab, 1986), 67.

${ }^{28}$ Siti Musdah Mulia, Menuju Kemandirin Politik (Upaya Mengakhiri Depolitisasi Perempuan di Indonesia) (Yogyakarta: Kibar Press, 2007), 144.

${ }^{29}$ Ibrahim Hashim Ibrahim, al-Mar'ah al-Muslimah wa Tawliha al-Wazaif al-'Ammah Bayna alMu'aradah wa al-Ta'yid (Kairo: Maktabh Wahbah, 2007), 110 
seperti dijelaskan dalam QS. al-Nisa [4]: 75. ${ }^{30}$ Oleh karena itu semua penafsiran yang bersifat menindas peran perempuan harus ditinjau kembali karena tidak sejalan dengan semangat al-Qur'an.

sebagian mereka menjadi penolong sebagian yang lain." Menurut Sayyid Qutb (1906-1966), dalam ayat ini terkandung makna tabiat orang mukmin, yaitu tabiat bersatu dan setia kawan, tabiat saling menjamin, saling menjamin di dalam merealisasikan kebaikan dan menolak kejahatan (ya'muruna bi alma'ruf wa yanhawna 'an al-munkar) "Mereka menyuruh yang ma'ruf, mencegah yang mungkar". ${ }^{31}$

Lebih jauh Sayyid Qutb menyatakan bahwa untuk merealisasikan kebaikan dan menolak kemunkaran itu memerlukan kesetiakawanan, saling menjamin, dan saling menolong. Karena itu, umat beriman harus berbaris dalam satu barisan, jangan sampai dimasuki oleh unsur-unsur perpecahan. Kalau terjadi perpecahan di kalangan golongan beriman, maka di sana tentu ada unsur asing yang menyimpang dari tabiatnya, menyimpang dari akidahnya, dan unsur inilah yang membawa perpecahan. Mungkin ada unsur kepentingan pribadi atau penyakit hati yang menghalangi implementasi sifat utama kaum mukminin dan menolaknya sifat yang telah ditetapkan oleh Tuhan Yang Maha Mengetahui lagi Mahawaspada. ${ }^{32}$

Mencermati pandangan Sayyid Qutb dalam ayat tersebut seoalah-olah ingin mengatakan bahwa jika kaum laki-laki (muknin) mengajak masyarakat melakukan suatu kebajikan dan melarang melakukan suatu kemunkaran maka perempuan diharapkan turut mendukungnya, demikian juga sebaliknya. Termasuk dalam hal ini, jika laki-laki yang menjadi pemimpin maka perempuan harus mendukung kepemimpinannya begitu pula sebaliknya, jika perempuan menjadi pemimpin maka laki-laki harus mendukung kepemimninan perempuan. Orang beriman laki-laki dan perempuan harus selalu kompak, saling mendukung, saling tolong menolong, dalam menjalankan tugasnya baik sebagai da'i atau pemimpin demi tercapainya kesuksesan dan terciptanya ketenteraman dan kedamaian dalam masyarakat. Mereka berdiri dalam satu barisan, setiakawan, senasib sepenanggungan jangan sampai disusupi unsur asing yang menyebabkan terjadinya perpecahan dan menyimpang dari akidahnya. Dalam hadith Rasulullah saw. dijelaskan bahwa orang-orang mukmin itu laksana suatu bangunan yang kokoh saling menguatkan satu sama lain. ${ }^{33}$

"Sebagian mereka menjadi penolong bagi sebagian yang lain"

\footnotetext{
${ }^{30}$ Nasaruddin Umar, Argumen Kesetaraan Gender Pespektif al-Qur'an (Jakarta: Paramadina, 2001), xxvxxvi. Siti Musdah Mulia, Menuju Kemandirian Politik Perempuan (Upaya Mengakhiri Depolitisasi Perempuan di Indonesia), 127.

${ }^{31}$ Sayyid Qutb, Fi Zilal al-Qur'an, jilid 3, 1675.

${ }^{32}$ Sayyid Qutb, Fi Zilal al-Qur'an, Jilid 3, 1675.

) المؤمن للمؤمن كالبنيان يثد بعضه بعضا : orang mukmin terhadap mukmin yang lain laksana suatu bangunan sebahagian menguatkan sebahagian lainnya). Abu Abd Allah Muhammad bin Isma'il bin Ibrahim ibn al-Mughirah bin Bardazabah al-Bukhari alJa'fi, Sahih Bukhari, Jilid 2, 81.
} 
Dengan mengarahkan kesetiakawanannya ini untuk melakukan amar ma'ruf dan nahi mungkar, menjunjung tinggi kalimat Allah, dan untuk merealisasikan pesan-pesan Allah untuk umat ini di muka bumi, "mereka mendirikan shalat", sebagai tali penghubung mereka dengan Allah, dan "mereka menunaikan zakat," sebagai suatu kewajiban yang dapat menjamin hubungan antarsesama anggota masyarakat muslim. Juga untuk merealisasikan kesetiakawanan dan saling menanggung dalam bentuk material dan spiritual. ${ }^{34}$

Ayat di atas memberi peluang kepada perempuan boleh berkiprah dalam berbagai bidang kehidupan, termasuk dalam bidang kepemimpinan dalam ranah domestik dan publik. Kebebasan berpendapat dan berpikir serta memiliki hak memilih dan dipilih. Terbukti keduanya berhak menyuruh mengerjakan yang ma'ruf dan mencegah yang munkar, mencakup segala segi kebaikan, termasuk memberi masukan dan kritik terhadap penguasa.

Dalam ajaran Islam, antara perempuan dengan laki-laki dipandang sama sebagai mahluk, hamba dan khalifah fil ard; keduanya mendapatkan kesamaan perintah untuk beriman, beribadah, perintah amar ma'ruf nahi munkar, perintah menegakkan nilai-nilai kebenaran, berbuat baik kepada sesama, dan sebaginya. Ayat-ayat al-Qur'an memanggil manusia dengan kata "ya ayyuha al-nas (hai manusia), ya ayyuha al-lazina amanu (hai orang-orang yang beriman), ya ulil albab (hai orang-orang yang cerdas), ya ulil absar (hai orang-orang yang berpandangan) semua ini merupakan panggilan untuk laki-laki dan perempuan.

Pada masa Rasulullah saw., tidak sedikit para sahabat perempuan ikut berpartisifasi dalam peran-peran politik yang cukup penting: Misalnya mereka tidak ketinggalan ikut bai'at bersama mitranya laki-laki di hadapan Rasulullah saw. mereka ikut serta berhijrah ke Madinah dalam rangka mencari suaka politik bersama-sama ikut membentuk komunitas persahabatan yang menciptakan persaudaraan antara kelompok Muhajirin dan Anshar. Contoh tersebut merupakan kenyataan dalam catatan sejarah yang mempertegas bahwa wilayah publik bagi perempuan tidak terlarang, tidak haram. Bahkan justru dengan keterlibatan perempuan di dalam pengambilan kebijakan publik, diharapkan akan menciptakan nilai-nilai keadilan dan kesetaraan dalam pembangunan.

Kenyataan sejarah menunjukkan sekian banyak di antara kaum perempuan yang terlibat dalam soal politik praktis. Ummu Hani misalnya, dibenarkan sikapnya oleh Nabi Muhammad saw. ketika memberi jaminan keamanan kepada sementara orang musyrik (jaminan keamanan merupakan salah satu aspek bidang politik). Bahkan istri Nabi Muhammad saw. sendiri, yakni 'Aisyah r.a., memimpin langsung peperangan melawan 'Ali ibn Abi Talib yang ketika itu menduduki jabatan Kepala Negara. Isu tersebar dalam peperangan tersebut adalah soal suksesi setelah terbunuhnya Khalifah ketiga, Uthman ibn 'Affan.r.a. Peperangan itu dikenal dalam

\footnotetext{
${ }^{34}$ Sayyid Qutb, Fi Zilal al-Qur'an, Jilid 3, 1675.
} 
sejarah Islam dengan nama perang Unta. Keterlibatan 'Aisyah r.a. bersama sekian banyak sahabat Nabi saw. dan kepemimpinannya dalam peperangan itu, menunjukkan bahwa dia bersama para pengikutnya itu menganut paham kebolehan keterlibatan perempuan dalam politik praktis sekalipun. ${ }^{35}$

Hak berpolitik adalah hak untuk berpendapat, hak untuk menjadi anggota lembaga perwakilan. Keterlibatan perempuan dalam politik bukan untuk menjatuhkan atau merebut kekuasaan laki-laki, apalagi menggeser lahan laki-laki, melainkan dimaksudkan agar perempuan benar-benar sebagai mitra laki-laki secara bersama-sama. Politik perempuan terkait dengan hak asasi manusia secara umum. Hak asasi dimiliki tanpa membedakan, berdasar suku, etnis, ras, budaya, jenis kelamin bahkan agama. Dasar hak asasi manusia memperoleh kesempatan untuk berkembang sesuai dengan bakat dan cita-citanya. ${ }^{36}$

Uraian tersebut di atas menunjukkan bahwa laki-laki dan perempuan mempunyai hak kepemimpinan publik. Terbukti keduanya berhak menyuruh mengerjakan yang ma'ruf dan mencegah yang mungkar, mencakup segala segi kebaikan, termasuk memberi masukan dan kritik terhadap penguasa. Di samping karena ditunjang oleh fakta historis pada masa Rasulullah saw. banyak kaum perempuan terlibat dalam peran-peran politik dan bahkan terlibat dalam soal politik praktis termasuk istri Rasulullah saw., sendiri yaitu Aisyah r.a., memimpin langsung peperangan melawan 'Ali Ibn Abi Talib.

\section{ANALISI HADITH KEPEMIMPINAN}

Hadith yang bersumber dari Abu Bakrah riwayat Bukhari tentang kepemimpinan perempuan menjadi perdebatan dikalangan para ulama, berikut hadith tersebut:

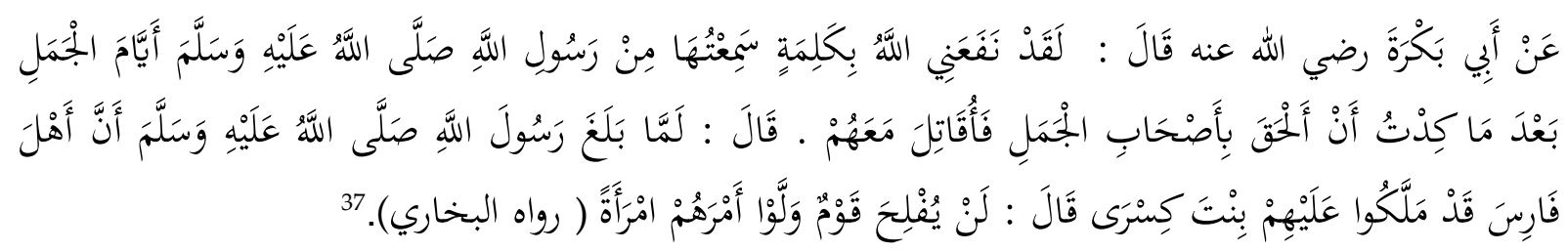

Artinya: Riwayat dari Abu Bakrah telah berkata: sungguh Allah telah memberikan manfaat kepadaku pada waktu perang jamal dengan kalimat yang saya dengar dari Rasulullah saw. setelah aku hampir bergabung dengan pasukan unta untuk bertempur bersama mereka, Abu Bakrah berkata: ketika ada berita sampai kepada Rasulullah saw., bahwa penduduk Persi telah mengangkat putri Kisra menjadi Ratu, maka Rasulullah bersabda:" Tidak akan beruntung suatu kaum yang menyerahkan urusan mereka kepada seorang perempuan." (HR. Bukhari).

Jumhur ulama memahami hadith tersebut secara tekstual. Mereka

\footnotetext{
${ }^{35}$ M.Quraish Shihab, Membumikan al-Qur'an: Funsi dan Peran Wahyu dalam Kehidupan Masyarakat (Bandung: Mizan, 1994), 274-275.

${ }^{36}$ Zaitunah Subhan, Menggagas Fiqh Pemberdayaan Perempuan (Jakarta: El-Kahfi, 2008), 113.

${ }^{37} \mathrm{Abu}$ 'Abd Allah Muhammad bin Isma'il bin Ibrahim ibn al- Mughirah al-Bukhari, Sahih al-Bukhari, Jilid 3 (Beyrut: Dar Ibn Kathir al-Yamamah, 1987), 89.
} 
berpendapat bahwa berdasarkan petunjuk hadith tersebut, pengangkatan perempuan menjadi kepala negara, hakim pengadilan, dan berbagai jabatan yang setara dengannya dilarang. Mereka menyatakan bahwa perempuan menurut petunjuk syara' hanya diberi tanggungjawab untuk menjaga harta suaminya. ${ }^{38}$

Quraish Shihab (1944) berpandangan lain bahwa hadith tersebut tidak bersifat umum, yang dapat dibuktikan dari redaksi hadith tersebut secara utuh, yang membicarakan masalah penduduk Persia ketika itu, bukan terhadap semua masyarakat dan dalam semua urusan. ${ }^{39}$ Hadith ini dikategorikan hadith sahih tetapi mempunyai latar belakang sejarah tersendiri (sabab wurud) ${ }^{40}$ sehingga tidak bisa serta merta langsung digunakan sebagai dalil umum. Hadith ini dipopulerkan oleh Abu Bakrah, yang diperhadapkan oleh suatu kondisi sulit, di mana harus memilih antara mendukung Ali, suami Fatimah atau mendukung 'Aisyah, istri Nabi saw. Dalam poisisi seperti ini, Abu Bakrah mempopulerkan hadith di atas karena ia berdiri di pihak 'Ali."1 Hadith ini merupakan respons spontanitas Rasululah saw. setelah mendengarkan raja Persi yang bernama Kisra telah wafat, dan kekuasaannya digantikan putrinya yang belum matang untuk memerintah. Nabi saw. memahami kondisi kerajaan Persi yang tengah menghadapi musuh, Romawi Bizantium. Pernyataan Rasulullah saw. di atas muncul dalam kapasitasnya sebagai pengamat politik. ${ }^{42}$ Husein Muhammad berpendapat, hadith ini diucapkan dalam kerangka pemberitahuan, sebuah informasi yang disampaikan Nabi saw. semata, dan bukan dalam kerangka legitimasi hukum. Dia menegaskan bahwa hadith ini tidak memiliki relevansi hukum. ${ }^{43}$

Salah satu syarat yang harus dimiliki oleh seorang pemimpin adalah kewibawaan, sedang perempuan pada saat itu sama sekali tidak memiliki kewibawaan untuk meminpin masyarakat. Dalam sejarah, penghargaan masyakat

\footnotetext{
${ }^{38}$ Ibnu Hajar al-'Asqalani, Fath al-Bari bi Sharh Sahih al-Bukhari (t.tp: Dar al-Matba'ah al-Salafiyah, 1407 H. Jilid 8, 128.

${ }^{39}$ M.Quraish Shihab, Wawasan al-Qur'an : Tafsir Maudhu'i atas Pelbagai Persoalan Umat (Bandung, Mizan, 1998), 314.

${ }^{40}$ Ibnu Hajar menjelaskan bahwa menurut tradisi yang berlangsung di Persia sebelum itu, yang diangkat sebagai kepala negara adalah seorang laki-laki. Tetapi yang terjadi pada tahun $9 \mathrm{H}$. itu menyalahi tradisi tersebut, yang diangkat sebagai kepala negara bukan seorang laki-laki, melainkan seorang perempuan, yakni Buwaran binti Syairawaih bin Kisra bin Barwaiz. Dia diangkat sebagai ratu (kisra) di Persia setelah terjadi pembunuhanpembunuhan dalam rangka suksesi kepala negara. Ketika ayah Buwaran meninggal dunia, anak laki-lakinya, yakni saudara laki-laki Buwaran, telah mati terbunuh tatkala melakukan perebutan kekuasaan. Karenanya, Buwaran lalu dinobatkan sebagai ratu (kisra).

Kakek Buwaran adalah Kisra bin Barwaiz bin Anusyirwan. Dia pernah dikirimi surat ajakan memeluk Islam oleh Nabi saw. Kisra menolak ajakan itu dan bahkan merobek-robek surat Nabi saw. Ketika Nabi saw. menerima laporan bahwa surat beliau telah dirobek-robek oleh Kisra, maka Nabi saw. bersabda bahwa siapa saja yang telah merobek-robek surat beliau, akan dirobek-robek (diri dan kerajaan) orang itu. Tidak berselang lama, kerajaan Persia hancur lebur berantakan dan berbagai pembunuhan yang dilakukan oleh keluarga dekat kepala negara. Ibnu Hajar al-'Asqalani, Fath al-Bari bi Sharh Sahih al-Bukhari, Jilid 8, 127-128.

${ }^{41}$ Nasaruddin Umar, Ketika Fikih Membela Perempuan, 194.

${ }^{42}$ Nasaruddin Umar, Ketika Fikih Membela Perempuan, 194-195.

${ }^{43}$ Husein Muhammad, Fiqh Perempuan: Refleksi Kiai atas Wacana Agama dan Gender (Yogyakarta:
} LKIS, 2001), 150. 
kepada kaum perempuan makin meningkat dan akhirnya dalam banyak hal, perempuan diberi kedudukan yang sama dengan laki-laki. Al-Qur'an sendiri memberikan kedudukan perempuan sama dengan laki-laki. Dalam keadaan perempuan telah memiliki kewibawaan dan kemampuan untuk memimpin, serta masyarakat bersedia menerimanya sebagai pemimpin, maka tidak ada salahnya perempuan dipilih dan diangkat sebagai pemimpin.

Untuk memahami sebuah hadith yang memiliki asbab al-wurud dengan baik, maka diperlukan pemahaman terhadap latar belakang sejarah munculnya hadith tersebut. Seperti telah dijelaskan di atas muncul karena dilatarbelakangi masalah khusus negara Persia. Tidak boleh digeneralisasi pada semua kasus. Jadi penggunaan hadith ini tidak bisa lepas dari kondisi sosial politik yang berkembang ketika itu, khususnya yang berkaitan dengan kepemimpinan negara Persi yang menjadi penyebab munculnya hadith ini. Menurut M. Syuhudi Ismail, hadith di atas harus dipahami secara kontekstual sebab kandungan petunjuknya bersifat temporal. ${ }^{44}$ Berdasarkan uraian dari beberapa pandangan para pakar di atas, maka sejatinya hadith tersebut dipahami secara kontekstual.

Makna hadith ini sama sekali tidak dapat dipertahankan jika dihadapkan pada fakta-fakta sejarah yang ada. Sejumlah perempuan telah terbukti mampu memimpin bangsanya dengan sukses dan gemilang, kisah tentang kebesaran Ratu Balqis, penguasa negeri Saba seperti yang diceritakan al-Qur'an dalam surah al-Naml dan al-Anbiya'. Kepemimpinannya terbilang sukses, negaranya makmur dan aman sentosa. Kesuksesan ini karena Balqis mampu mengatur negaranya dengan sikap dan pandangannya yang demokratis. ${ }^{45}$ Indira Gandi, Margaret Tatcher, Srimavo Bandaranaeke, Benazir Butho dan lainnya adalah beberapa contoh dari pemimpin bangsa di masa modern yang relatif sukses. ${ }^{46}$

Pujian al-Qur'an dalam surah al-Naml tentang kesuksesan Ratu Balkis tentu dapat dijadikan salah satu indikator penting tentang pandangan Islam yang positif

\footnotetext{
${ }^{44}$ M. Syuhudi Ismail, Hadith Nabi Yang Tekstual dan Kontekstual: Telaah Ma'ani al-Hadith tentang ajaran Islam yang Universal, Temporal, dan lokal (Jakarta: PT.Bulan Bintang, 1994), 67.

${ }^{45}$ Kabar tentang adanya suatu kekuasaan tangguh diperoleh Nabi Sulaiman melalui informasi dari burung hud-hud. Melalui perantaraan burung Nabi Sulaiman mengirim surat sakti (kitab karim menurut istilah Balqis) yang intinya mengajak Ratu Balqis untuk menjalin hubungan diplomatik (QS. al-Naml [27:29]. Sebagai Ratu yang demokratis, Balqis tidak langsung mengambil keputusan sendiri. Balqis mengajak pembesarnya bermusyawarah: "Wahai para pembesar berilah aku pertimbangan dalam urusan ini, aku tidak pernah memutuskan sesuatu persoalan sebelum kalian berada di dalam mejelisku (QS.al-Naml [27]:32). Para Pembesarnya menjawab: "Kita memiliki potensi kekuatan dan keberanian,dan keputusan berada di tanganmu, maka pertimbangkanlah apa yang kamu perintahkan." (QS.al-Naml [27]:33. Sama halnya Nabi Sulaiman mengajak para pembesarnya bermusyawah dalam menghadapi kemungkinan sikap yang akan ditempuh oleh kekuatan Balqis. Karena keduanya menjunjung tinggi nilai-nilai musyawarah dan demokratis, akhirnya kedua kubu ini bertemu dan bersatu. Kedua tokoh ini sama-sama memasuki istana seperti disebutkan dalam QS. alNaml [27]:44). Bahkan keduanya melangsungkan perkawinan dan melahirkan generasi baru yang tangguh. Keberuntungan dari hasil pertemuan kedua tokoh tesebut adalah bersatunya dua kekuatan, rakyat menjadi aman, stabil, terhindari dari malapetaka peperangan dan terwujudnya ksesejahteraan dalam masyarakat. Nasaruddin Umar, Ketika Fikih Membela Perempuan, 197.

${ }^{46}$ Husein Muhammad, Fiqih Perempuan Refleksi Kiyai atas Wacana Agama dan Gender, 150.
} 
dan apresiatif terhadap kompetensi dan kapabilitas perempuan yang menduduki jabatan penting. Kesuksesan atau kegagalan dalam memimpin suatu bangsa tidak terkait dengan persoalan jenis kelamin, tetapi lebih pada sistem yang diterapkan dan kemampuannya memimpin.

\section{PENUTUP}

Perempuan mempunyai hak menjadi pemimpin baik dalam ranah domestik maupun dalam ranah publik. Para Mufassir kontemporer sepakat bahwa QS.alNisa'/4:34 berbicara dalam konteks urusan keluarga tidak ada hubungannya dengan soal hak politik perempuan. Demikian juga kepemimpinan dalam masyarakat tidak ada kaitannya dengan kewajiban memberi nafkah terhadap masyarakat yang dipimpinnya, tetapi hanya berkaitan dengan kewajiban melaksanakan tanggungjawabnya dan menegakkan keadilan terhadap masyarakat yang dipimpinnya. Ayat al-Nisa tersebut dan hadith riwayat al-Bukhari mereka menafsirkan secara kontekstual.

Mereka juga sepakat perempuan mempunyai hak kepemimpinan publik sama dengan laki-laki, keduanya berhak menyuruh mengerjakan yang ma'ruf dan mencegah yang munkar, termasuk memberi masukan dan kritik terhadap penguasa. Hal ini ditegaskan dalam QS.al-Taubah/9:71. Ditunjang pula dengan fakta sejarah, seorang perempuan dikisahkan al-Qur'an, Ratu Balqis penguasa negeri Saba'.Kepemimpinannya terbilang sukses, negaranya makmur dan aman, karena mampu mengatur negaranya dengan sikap pandangannya yang demokratis. Islam memberi kebebasan berpendapat dan berfikir dan boleh mengemukakan pendapat dalam bermusyawarah. Islam tidak membatasi hak perempuan dalam mengurus kepentingan publik, hanya saja perlu disesuaikan dengan kemampuan dan kehormatan perempuan sendiri.

\section{Daftar Pustaka}

Al-Asfahani, Husayn bin Muhammad. al-Mufradat fi Gharib al-Qur'an. Kairo: Mustafa al-Bab al-Halabi, 1961.

al- Asqalani, Ahmad ibn 'Ali ibn Hajar. Fath al-Bari bi Sharh Sahih al-Bukhari. t.t.: Dar al-Matba'ah al-Salafiyah, 1407.

al-Bukhari, Muhammad Ibn Isma'il Abu 'Abdillah, Sahih Bukhari, Beirut: Dar Ibn Kathir al-Yamamah, 1987.

Departemen Agama RI. al-Qur'an dan Terjemahnya. Jakarta: Yayasan Penyelenggara Penerjemah/Penafsir al-Qur'an, 1971.

Husein Muhammad. Figh Perempuan Refleksi Kiai atas Wacana Agama dan Gender: 
Yogyakarta: LKIS, 2001.

Ibn 'Ashur, Muhammad Tahir. Tafsir al-Tahrir wa al-Tanwir. Tunis: Dar Sahnun, t.th. Ibn Kathir, Abu al-Fida' Isma'il. Tafsir al-Qur'an al- 'Azim. t.t: Dar al-Fikr dan Isa alBab al-Halabi, t.th.

Ibrahim, Ibrahim Hashim. Al-Mar'ah al-Muslimah wa Tawalliyaha al-Wazaif al-'Ammah bayna al-Mu'aradah wa al-Ta'yidi. Kairo: Maktabah Wahbah, 2007.

Ismail, M.Syuhudi. Hadith Nabi Yang Tekstual dan Kontekstual: Telaah Ma 'ani alHadith tentang Ajaran Islam yang Universal, Temporal dan Lokal. Jakarta: PT.Bulan Bintang, 1994.

Istibsyorah. Hak-Hak Perempuan Relasi Gender Menurut Tafsir al-Sha'rawi. Jakarta: Teraju, 2004.

Muhammad Mahmud, Jamaluddin. Huquq al-Mar'ah fi al-Mujtam'al-Islam Mesir: alHaiah al-Misriyah al-'Ammah li al-Kitab, 1986.

Mulia, Musdah. Menuju Kemandirian Politik Perempuan (Upaya Mengakhiri Depolitisasi

Perempuan di Indonesia). Yogyakarta: Kibar Press, 2009.

Qutb, Sayyid. Fi Zilal al-Qur'an. Mesir: Dar al-Syuruq, 2011. Cet.ke-39.

Rida, Muhammad Rashid. Tafsir al-Manar. Cairo: Dar al-Manar, t.th.

al-Sabuni, Muhammad 'Ali. Safwat al-Tafasir. Beyrut: Dar al-Qur'an al-Karim. 1981, Jilid 1.

al-Sha'rawi, Muhammad Mutawalli. Tafsir al-Sha'rawi. Kairo: Shirkah al-Sautiyah wa al-Mar'iyyah, t.th.

Shihab, M.Quraish. Membumikan al-Qur'an. Jilid 2, Jakarta: Lentera Hati, 2010.

Shihab, M.Quraish. Membumikan al-Qur'an Fungsi dan Peran Wahyu Dalam Kehidupan Masyarakat. Bandung: Mizan, 1994.

.Tafsir al-Misbah, Pesan, Kesan dan Keserasian al-Qur'an. Jakarta: Lentera Hati, 2008.

Subhan, Zaitunah, Tafsir Kebencian: Studi Bias Gender dalam Tafsir al-Qur'an, Yogyakarta: LKIS, 1999.

Subhan, Zaitunah. Rekonstruksi Pemahaman Gender Dalam Islam: Agenda Sosio-Kultural dan Politik Peran Perempuan. Jakarta: El-Kahfi, 2002.

--------. Perempuan dan Politik dalam Islam. Yogyakarta: Pustaka Pesantren, 2004.

al-Tabataba'i. Muhammad Husain, Tafsir al-Mizan. Teheran: Dar al-Kutub al'Ilmiyah, t.th.

Umar, Nasaruddin. Argumen Kesetaraan Gender Perspektif al-Qur'an. Jakarta: Paramadina, 2001.

Ketika Fikih Membela Perempuan. Jakarta: PT.Gramedia, 2014.

al-Yasu'i, Louis Makhluf. al-Munjid fi al-Lughah wa al-Adab wa al-'Ulum. Beyrut: alKathilliyyah, 1986. 